\title{
RESEARCHPAPER
}

\section{Biochemical constituents of Alternaria blight of pathogens in pigeonpea}

\author{
LAXMAN PRASAD BALAI ${ }^{1}$, A. SINHA ${ }^{2}$, R.B. SINGH ${ }^{2}$ AND S.M. YADAV ${ }^{2}$ \\ ${ }^{1}$ ICAR-CAZRI, Krishi Vigyan Kendra, PALI-MARWAR (RAJASTHAN) INDIA \\ ${ }^{2}$ Department of Mycology and Plant Pathology, Institute of Agricultural Sciences, Banaras Hindu University, \\ VARANASI (U.P.) INDIA \\ Email : Laxmanbhu08@gmail.com
}

Article Info : Received : 08.02.2017; Revised : 05.03.2017; Accepted : 18.03.2017

The common biochemical constituents like chlorophyll and carotenes are important in imparting resistance to the crop plants. Distinct variation in chlorophyll content of pigeonpea leaves of a set of twelve genotypes which were inoculated with representatives ten isolates. In the chlorophyll 'a', chlorophyll 'b', total chlorophyll and carotene content have recorded in higher amounts in resistant genotypes (ICP-7220, IPA-7-2) followed by moderately resistant (ICP-13174 and DA-11) and moderately susceptible (ICP-11294 and ICP-4725), whereas lower amount susceptible (BSMR-736 and ICP-7182) genotypes and highly susceptible genotypes (MAL-24, Bahar). The maximum chlorophyll and carotene content were found in resistant genotypes at early stage of plants with minimum reduction whereas, lowest content was found in susceptible genotypes old plants with highest reduction. It showed same trend in a-virulent isolates in which lowest reduction chlorophyll and carotenes content were found as compared to virulent (aggressive) isolates.

Key words : Genotypes, Resistance, Isolates, Alternaria, Chlorophyll, Carotene

How to cite this paper: Balai, Laxman Prasad, Sinha, A., Singh, R.B. and Yadav, S.M. (2017). Biochemical constituents of Alternaria blight of pathogens in pigeonpea. Asian J. Bio. Sci., 12 (1) : 1-7.DOI : 10.15740/HAS/AJBS/12.1/1-7. 